\title{
Remarks on the philosophy of Idokan Karate
}

\author{
Wojciech J. CYNARSKI ${ }^{* 1}$ \\ ${ }^{1}$ University of Rzeszow (Poland)
}

8th IMACSSS International Conference Abstracts, Viseu (Portugal), October 10-12, 2019

Type: Oral communication

\begin{abstract}
Every school of karatedo presents some special values and norms. May be, the philosophy of Idokan Karate is partially similar to other schools, and especially represents the Ido philosophy (that is not worldwide known). It is a real, practical philosophy, internalised and used by groups of karateka, as a form of today's warrior pathway. The author tries to answer the following questions: What ethics, values and rules are prominent in Idokan Karate? What is the specific, symbolic content of this style and school? This is a single case study, involving a content analysis of literature and the wider discourse, and the hermeneutic phenomenology. The study uses the analysis of broad discourse, which concerns both scientific studies and popularizing publications. Not without significance is the fact that the author has actively practiced Asian martial arts for over 40 years. The specific, symbolic content of Idokan Karate is taken from philosophic Taoism, Chinese and Japanese tradition of martial arts, and from Christianity. Its interpretation shows that the karate athlete has to go the moral way. It is the pathway toward being a better human. Such teleology comes from special values, rules and aims. In the normative ethics, the Decalogue and the idea of nobility (the Homo creator nobilis) are most important. Tao in Idokan Karate is understood as God's Word, the principle of love and the way of the Heavens.
\end{abstract}

Keywords: Martial arts; values; aims; karate; Idokan.

\section{Introduction}

Karate and other martial arts have gained global popularity. They are said to be the movement forms of Eastern philosophy (Tokarski, 1989). One can also agree that they are a practical philosophy in the sense that martial arts philosophy is carried out by the everyday practice of appropriate, psycho-physical exercises (Kim \& Back, 2000; Mayen, Johnson, \& Mayen Bosch, 2015). Every day karateka should overcome their weaknesses and become better persons. At least that is the general assumption of the "karate way".

\section{Objectives}

What is the purpose of these exercises, or what is the goal of the "path" that the Taoism philosophy and the tradition of many martial arts are talking about? We will try to answer this question only indirectly, pointing to the hierarchies of values and main goals adopted in individual cases. We will describe more closely the case of the style, school and organisation Idokan, comparing it to other varieties of multiform karate. What ethics, values and rules are prominent in Idokan Karate? What is the specific, symbolic content of this style, school and organisation?

\section{Methodology}

This is a case study (the descriptive, interpretative, and evaluative study of a single case) (Skinner, Edwards, \& Corbett, 2015, pp. 116-133), which employs hermeneutic phenomenology (pp. 206-217) and a content analysis of literature and the wider discourse (Krippendorf, 2004). The study uses the analysis of broad discourse, which concerns both scientific studies and popularizing publications. Not without significance is the fact that the author has actively practiced Asian martial arts for over 40 years, and is a teacher of Idokan Karate. This is a source of knowledge from direct

\footnotetext{
*Email: ela cyn@wp.pl
} 
experience, highly valued in the philosophy of East Asia (Wyka, 1993). The biopsychosocial phenomenon of experience is also of high interest for the social sciences of sport (Thiel, John, \& Frahsa, 2019).

\section{Results}

Karateka are supposed to be strong and courageous, but they cannot use their skills for evil purposes, because it would cause complete degradation. Only in the defence of life has the real utilization of karate skills the right way (which is highlighted in Sieber's school, too) (Burrow, 2014). Idokan Karate derives from the style or direction of Zendo Karate represented by the schools of Lothar Sieber. Shihan L. Sieber (now meijin, 10 th dan in both karate and jujutsu) introduced the Ido concept into karate. He created Idokan Karate (Sieber, 2001). However, the idea of Ido was born in Australia thanks to Dr. Wally Strauss, Grand Master of Idokan organisation. "Currently Ido is, in the teaching of Hans Schöllauf, the development of spiritual strength and 'perpetual' spiritual movement. Movement is the essence of life. Ido combines components of movement, harmony and spirit. It strives towards a state of psychophysical harmony and rejects the selfish attitude of openness; it seeks spiritual mastery while maintaining the best possible health and fitness. It implements the demands of physical culture." (Cynarski, 2017, p. 102). This "perpetual movement" in physical form is taught in Honbu in Munich and in dojos under the umbrella of IPA - in karate and jujutsu techniques.

What ethics, values and rules are prominent in Idokan Karate? Generally - Christian, chivalrous, but also from humanized bushido, plus some Taoist and Stoic threads. For example, the "water principle" is used, which is common for jujutsu and Zendo Karate, and it is derived from philosophical Taoism, but is applied here in relation to the tactics of struggle. So as "adapting to the situation" - like water to the shape of the dish. The principle of flexibility is similarly explained.

\section{Discussion}

Martial art is both a teaching system and the effects of this process. Historically, it served to prepare a warrior for battle. However, today the "fight" itself can be treated as a goal or as a means. Evolution came from martial techniques, through martial arts (including, incidentally, according the humanistic theory of martial arts - spiritual improvement), to the martial pathway. The latter are indeed more educational systems than teaching the ways of killing (Johnson, 2017; Cynarski, 2019). One of the "paths of truth" is the moral way of martial arts. This is not a blind imitation of patterns from the Far East. Developed by European masters, Idokan Karate is innovative in technical solutions, but also original in its philosophical foundations. Peter K. Jahnke pointed to humanism and a new sense of struggle (mutual learning in the dojo or real self-defence in a real threat situation). Lothar Sieber pointed to the Decalogue as the basic moral signpost.

\section{Conclusion}

The specific, symbolic content of Idokan Karate is taken from philosophic Taoism, Chinese and Japanese tradition of martial arts, and from Christianity (chivalry, St. Michael, St. George). Its interpretation shows that karateka (karate athlete, master or student) has to go the moral way. It is the pathway toward being a better human being. Such teleology comes from special values and rules, and aims. In the normative ethics, the Decalogue and the idea of nobility (the Homo creator nobilis) are of the utmost importance. Tao in Idokan Karate is understood as God's Word, the principle of love and the way of the Heavens.

\section{References}

Burrow, S. (2014). Martial arts and moral life. In G. Priest \& D. Young (Eds.), Philosophy and the Martial Artse (pp. 50-67). London - New York: Routledge.

Cynarski, W.J. (2017). The philosophy of martial arts - the example of the concept of Ido. AUC Kinanthropologica, 53(2), 95-106. doi: 10.14712/23366052.2017.7

Cynarski, W.J. (2019). General canon of the philosophy of karate and taekwondo. Ido Movement for Culture. Journal of Martial Arts Anthropology, 19(3), 24-32. doi: 10.14589/ido.19.3.3 
Johnson, J.A. (2017). From technique to way: an investigation into taekwondo's pedagogical process. Ido Movement for Culture. Journal of Martial Arts Anthropology, 17(4), 3-13. doi: 10.14589/ido.17.4.2

Kim, D., \& Back, A. (2000). The Way to Go: Philosophy in Martial Arts Practice. Seoul: Nanam.

Krippendorf, K. (2004). Content Analysis: An Introduction to Its Methodology. Thousand Oaks, CA: Sage.

Mayen, J., Johnson, J.A., \& Mayen Bosch, R. (2015). Taekwondo as one's life philosophy. The Journal of the International Association for Taekwondo Research 2(1), 24-29.

Sieber, L. (2001). Characteristics of Idokan karate. Ido - Ruch dla Kultury / Movement for Culture, 2 , 26-27.

Skinner, J., Edwards, A., \& Corbett, B. (2015). Research Methods for Sport Management. London New York: Routledge.

Thiel, A., John, J., \& Frahsa, A. (2019). Qualitative interviews in sport and physical activity research do not forget the body. European Journal for Sport and Society, 16(1) 1-4. doi: $10.1080 / 16138171.2019 .1616423$

Tokarski, S. (1989). Sztuki walki. Ruchowe formy filozofii Wschodu. Szczecin: Glob.

Wyka, A. (1993). Badacz społeczny wobec doświadczenia. Warsaw: IFiS PAN. 